baf- $\odot$

Proceedings of the Berner

Altorientalisches

Forum

ISSN 2504-2076

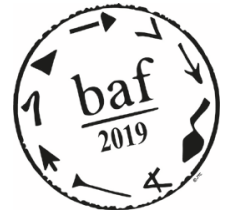

Abstract

Armando Bramanti

Université de Genève

DOI: http://doi.org/10.22012/baf.2019.30

\title{
Toward a Syllabary and a Sign List of the Early Dynastic Umma Region
}

After its decipherment in the middle of the 19th century, cuneiform came to be, together with its numerous recently discovered inscriptions, the object of intense attention on the part of both scholars and the general public. The first Old Persian and Neo-Assyrian monumental findings triggered the compilation of several sign lists, some of them still in use today. The discovery of older cuneiform archives, some of them dating to the end of the fourth and to the first half of the third millennium, made new approaches to cuneiform epigraphy and the compilation of new repertoires of signs necessary. After almost a century and in spite of its limited chronological and geographical scope, Deimel's Liste der Archaischen Keilschriftzeichen (LAK, 1922) is still the standard sign list used for the Early Mesopotamian texts. In recent years the discovery of hundreds of new texts in several southern Mesopotamian regions compelled cuneiformists to create new tools for the epigraphic study of this material. In this talk I will present the ongoing work and the preliminary results of my current research project on the paleography of the Early Dynastic Umma Region, showing its potentialities and highlighting the critical issues in the creation from scratch of a cuneiform syllabary and sign list. 